\title{
APLIKASI KONSEP FITOTEKNOLOGI DALAM PEMBELAJARAN BIOLOGI PADA SEKOLAH HIJAU
}

\author{
Hening Widowati \\ Pendidikan Biologi FKIP Universitas Muhammadiyah Metro. \\ E-mail: hwummetro@gmail.com
}

\begin{abstract}
Phytotechnology plays as integral strategy for planning and environment sanitation process. Phytoprocess on phytotechnology makes possible the realization of healthy environment mission, because plant have ability to recycle material, as natural so as environment resources conservation technology, which essential in continuously development. Green school have commitment with systematic develop programs for internalyzing environment value to school activity. Applying phytotechnology concept is systematic strategy for realization of biology learning at Green School Education Program.
\end{abstract}

Kata kunci: fitoteknologi, sekolah hijau

Fitoteknologi telah dimanfaatkan manusia sejak dahulu kala bahkan pada sekitar 3000 tahun Sebelum Masehi, sebagai teknologi alamiah tumbuhan, yang mempunyai misi penyehatan lingkungan dalam mendukung kesehatan manusia, memperkaya dan memperkuat cara penyelesaian masalah lingkungan yang makin kompleks. Tumbuhan mempunyai kemampuan dan taat azas dalam mendaur ulang materi secara alamiah, sehingga menjadikan fitoteknologi setara teknologi konservasi sumberdaya lingkungan, yang esensial dalam pembangunan berkelanjutan.

Secara umum, fitoteknologi adalah penerapan ilmu dan teknologi untuk mengkaji dan menyiapkan solusi masalah lingkungan dengan menggunakan tumbuhan. Fitoteknologi digunakan untuk memperluas pengertian mengenai pentingnya tumbuhan dan peranannya dalam sistem kehidupan masyarakat dan lingkungan. Konsep fitoteknologi adalah memusatkan tumbuhan sebagai teknologi lingkungan hidup yang mampu menyelesaikan masalah lingkungan. Sedangkan proses tumbuhan untuk menyerap, mengambil, mengubah dan melepaskan kontaminan dari satu medium ke mediaum lain digunakan istilah fitoremediasi. Dalam tinjauan teknologi dan proses-proses yang terjadi dalam fitoremediasi, memperjelas fitoteknologi sebagai cara pendekatan berbasis alam dalam penyelesaian masalah lingkungan.

Sekolah sebagai lembaga sosial memiliki peran strategis bagi masa depan bangsa. Peran sekolah di antaranya adalah membantu anak memperoleh pengetahuan, ketrampilan; membantu anak mempelajari cara penyelesaian masalah-masalah kehidupan, baik sebagai masalah individu maupun masalah masyarakat; membantu anak mengembangkan, memperbaiki mutu dan kualitas kehidupan manusia (Nawawi, dalam Handoyo, 2002). Paradigma pendidikan yang demikian mendorong anak didik untuk memberdayakan dirinya dan bertanggungjawab pada lingkungannya.

Berdasarkan visi tersebut, sekolah mempunyai peranan yang besar untuk 
menghasilkan generasi yang mempunyai pengetahuan luas, terampil memecahkan masalah dan bertanggungjawab atas keputusan yang diambilnya. Untuk menopang visi demikian, sekolah hijau merupakan alternatif pendidikan yang menerapkan konsep fitoteknologi yang mampu menyelesaikan masalah lingkungan yang kontektual bagi anak didik. Dalam artikel ini diuraikan hal-hal pokok: 1) Konsep Fitoproses pada Fitoteknologi; 2) Sekolah Hijau; dan 3) Strategi aplikasi konsep fitoteknologi pada sekolah hijau.

\section{Konsep Fitoproses pada Fitoteknologi}

Temuan teknologi lama

mengemukakan, tumbuhan dapat digunakan untuk perancangan dan proses sanitasi lingkungan. Melalui metode fitostruktur, dengan menata luas dan sebaran Ruang Terbuka Hijau (RTH) untuk tumbuhan, yang ditujukan untuk menyerap karbondioksida dari hasil aktivitas manusia dan untuk mencegah dampak lingkungan yang buruk. RTH telah menjadi kesatuan program pembangunan di banyak negara dan diintensifkan untuk mengatasi pemanasan global yang disebabkan peningkatan karbondioksida di udara. Manusia dan tumbuhan memerlukan air untuk respirasi dan menghasilkan karbondioksida. Tumbuhanlah satusatunya yang mempunyai tanggungjawab menyerap karbondioksida untuk prosesnya menjalankan fotosintesis. Pengaturan fitostruktur adalah penting dan diperlukan untuk pengelolaan kuantitas lingkungan berkaitan fluktuasi ketersediaan dan penggunaan air, emisi karbondioksida; yang kesemuanya dipengaruhi oleh faktor jumlah dan aktivitas penduduk, topografi, serta sebaran dan pola RTH.

Telah dipahami bahwa pertumbuhan tumbuhan memerlukan air dari tanah dan karbondioksida dari udara. Air tanah diserap sejalan dengan proses transpirasi, yang umumnya berjalan di hari terang. Pada tanah tercemar, tumbuhan dan/atau kombinasinya dengan mikroba tanah akan melakukan imobilisasi dan pengambilan zat kimia. Proses pengurangan kontaminan oleh tumbuhan dikenal sebagai fitoremediasi, yang mencakup delapan proses (Peer et al., 2003; Mangkoedihardjo, 2008), yaitu 1) fitostabilisasi, 2) rizofiltrasi/ fitofiltrasi/fitoimobilisasi, 3) rizodegradasi, 4) fitoekstraksi/ fitoakumulasi/ fitoabsorbsi/fitoserapan, 5) fitodegaradasi/fitolignifikasi/fitotransforma si, 6) fitovolatilisasi, 7) kontrol hidrolik air tanah, 8) kap vegetasi/kap evapotranspirasi/pelindung kesetimbangan air. Prinsipnya fitoproses adalah pemanfaatan tumbuhan dalam penyelesaian berbagai masalah pengolahan seperti sumber air, air limbah, dan lindi.

Fitostabilisasi, inaktivasi tempat, atau hiperakumulasi adalah proses imobilisasi kontaminan dalam tanah. Rizofiltrasi, fitofiltrasi, atau fitoimobilisasi merujuk proses adsorpsi atau presipitasi kontaminan pada akar atau penyerapan ke dalam akar, sedangkan rizodegradasi atau penguatan biodegradasi rizosfer adalah proses penguraian kontaminan dalam tanah oleh aktivitas mikroba, yang mendapat pasokan sumber karbon organik dari tumbuhan. Fitoekstraksi, fitoakumulasi, fitoabsorpsi, atau fitoserapan adalah proses pengambilan kontaminan dan terdistribusi ke dalam berbagai organ tumbuhan. Fitodegradasi, fitolignifikasi, atau fitotransformasi adalah penguraian kontaminan yang terserap melalui proses metabolik dalam tumbuhan, atau penguraian kontaminan di luar tumbuhan melalui proses enzimatik yang dihasilkan tumbuhan. Keseluruhannya adalah penguraian kontaminan yang dapat diikat tumbuhan, atau bahkan sebagian menjadi nutrisi tumbuhan. Fitovolatilisasi adalah 
proses pelepasan kontaminan ke udara setelah terserap tumbuhan. Kontaminan terserap bisa berubah struktur kimianya sebelum lepas ke udara.

Fitovolatilisasi dipengaruhi oleh transpirasi dan karenanya, tumbuhan dapat menyerap banyak air tanah, terutama di daerah tropis dan tersedia RTH luas. Hasilnya, tinggi air tanah akan naik dan kontaminan terakumulasi di permukaan tanah, sehingga pencemaran air tanah dapat ditekan. Mekanisme demikian menjadikan fitoteknologi sebagai kontrol hidrolik air tanah. Fungsi penting lainnya tumbuhan adalah sebagai kap vegetasi, kap evapotranspirasi, atau pelindung kesetimbangan air. Prosesnya adalah menahan air hujan untuk kemudian diuapkan kembali ke udara. Sebagai payung hijau, maka proses tersebut merupakan pengendali air hujan dan mengurangi masuknya kontaminan ke kedalaman tanah saat musim penghujan. Tumbuhan sebagai payung hijau merefleksikan kemampuannya melindungi lahan tercemar dari hujan sekaligus memulihkannya, serta mampu menonjolkan manfaat lahan hijau tak tercemar untuk menampung air hujan yang merupakan keuntungan dalam siklus hidrologis.

Fitoteknologi dapat diarahkan untuk pengolahan limbah. Air limbah perkotaan dan industri dipertimbangkan sebagai sumber masalah serius lingkungan perkotaan Limbah organik bersifat sulit terurai biologis karena dapat bertahan lama di lingkungan. Eliminasinya dilakukan melalui pengolahan pendahuluan dengan memanfaatkan fitoteknologi (misalnya tumbuhan eceng gondok dan lainnya) untuk meningkatkan rasio BOD/COD sehingga mudah terurai biologis (biodegradable). Peningkatan rasio BOD/COD kecil dapat dilakukan secara pengolahan fisik menggunakan proses hidrotermal, oksidasi fotokatalisa ultra violet, dan ozonisasi; secara kimiawi dengan penambahan karbohidrat; secara pengolahan mikrobial menggunakan kombinasi proses anaerobik dan aerobik. Penggunaan eksudat tumbuhan mengandung asam organik, fenol, enzim dan protein yang semuanya mudah terurai biologis. Suatu campuran limbah organik dengan rasio $\mathrm{BOD} / \mathrm{COD}$ kecil dan eksudat dengan rasio BOD/COD tinggi dapat menghasilkan limbah organik mudah terurai biologis. Fakta tersebut menunjuk fitoteknologi dapat diterapkan mendahului proses mikrobial pengolahan limbah. Di samping air limbah, tempat pembuangan sampah juga memerlukan tumbuhan, maka lindi sampah dapat diolah tumbuhan untuk pengambilan kontaminan. Saat berhadapan dengan masalah tempat tercemar dalam pelaksanaan pengelolaan sampah, sanitasi, dan lingkungan umumnya, maka fitoremediasi menawarkan potensi tumbuhan untuk memulihkannya. Dalam praktek, fitoremediasi dapat diterapkan sebagai cara memperbaiki kualitas tempat tercemar dengan menggunakan tumbuhan. Tempat yang dipulihkan itu dapat digunakan kembali untuk tempat sebelum tercemar atau maksud penggunaan lainnya. Secara khusus lahan bekas tempat pembuangan sampah, perairan tercemar, tanah tercemar, sedimen tercemar akan menjalani rehabilitasi melalui proses fitoremediasi yang prosesnya sama dengan proses pengolahan limbah.

\section{Sekolah Hijau}

Pendidikan lingkungan hidup merupakan usaha untuk melestarikan lingkungan yang dilakukan dari generasi sekarang ke generasi yang akan datang. Secara eksplisit menunjukkan bahwa perjuangan manusia untuk melestarikan dan menyelamatkan lingkungan hidupnya, supaya tidak terjadi kepunahan dan tetap 
terjaga daya dukung lingkungan harus dilakukan secara berkesinambungan, dengan jaminan estafet antar generasi. Pendidikan lingkungan hidup harus dilakukan secara terprogram dan berkelanjutan, dengan memasukkan materinya secara integratif suatu mata pelajaran, dengan harapan lebih meningkatkan pemahaman, sikap, dan perilaku siswa terhadap lingkungannya. Karena itulah sekolah hijau merupakan alternatif pendidikan lingkungan hidup. Sekolah hijau merupakan sekolah yang memiliki kebijakan positif dalam pendidikan lingkungan hidup, artinya dalam segala aspek kegiatannya mempertimbangkan aspek lingkungan (Susilo, 2001), memiliki komitmen dan secara sistematis mengembangkan program-program menginternalisasikan untuk nilai-nilai lingkungan ke dalam aktivitas sekolah. Program sekolah hijau dikembangkan melalui 5 kegiatan utama: 1) Mengembangkan kurikulum berwawasan lingkungan; 2) Peningkatan kualitas kawasan sekolah dan lingkungan sekitarnya; 3) Pengembangan pendidikan berbasis komunitas; 4) Pengembangan sistem pendukung yang ramah lingkungan dan 5) Pengembangan manajemen sekolah berwawasan lingkungan.

Menurut Handoyo (2002), secara konsepsual greening school dapat diartikan sebagai program pendidikan yang bertujuan untuk menumbuhkembangkan sikap dan perilaku konstruktif pada diri siswa, guru, dan kepala sekolah terhadap permasalahan lingkungan yang ada di sekolah dan sekitarnya. Greening school memiliki prinsip: 1) Dapat diimplementasikan pada lingkungan sekolah bagaimanapun keadaannya/free of space, 2) Konsep yang bersifat proaktif/tidak dipaksakan, berjalan natural, berdasarkan kesiapan dan kebutuhan bersama, 3) Beranjak dari situasi yang menyenangkan/joyful learning, 4) Berorientasi pada upaya menumbuhkembangkan kesadaran tindakan siswa terhadap masalah lingkungan hidup di sekolah sebagai bagian dari keseluruhan masalah lingkungan secara global, 5) Merupakan nilai yang dinamis, realistis, objektif dan berupaya memperbaikinya secara nyata.

Menurut Turcotte (2003), petunjuk praktis dalam melaksanakan sekolah hijau yang komprehensif meliputi: 1) Indoor Air Quality (kondisi udara ruangan alami dengan ventilasi cukup/pendinginpenghangat ruangan yang terpelihara; 2) Problem Pest (bebas racun pestisida); 3) Waste Management Program (recycling \& composting); 4) Energy Efficient; 5) Environmental Management System; 6) Building Material and Product Usage; 7) Curriculum 8) Water Convervation and Reuse (melakukan pengolahan limbah); 9) Toxic Chemical (menjaga sekolah dari racun kimia); 10) Landscaping (pengelolaan halaman sekolah dengan penataan untuk fungsi-fungsi tertentu);11) Environmental, Health and Safety (menciptakan lingkungan yang baik, sehat dan aman); 12) Dust / menjaga kebersihan dari debu.

Menurut Minggu Alam Sekitar Malaysia/MASM (2004, dalam Sumarmi, 2008), tujuan sekolah hijau adalah: 1) Meningkatkan kesadaran siswa dalam memelihara lingkungan sekolah; 2) Memupuk sikap positif dan cinta lingkungan di kalangan warga sekolah; 3) Membentuk lingkungan sekolah yang menitikberatkan pemeliharaan sumberdaya alam; 4) Berusaha untuk membuat sekolah melaksanakan pendidikan lingkungan hidup yang berkelanjutan (Kementrian Sumber Asli dan Alam Sekitar, 2004).

Menurut MASM (2004, dalam Sumarmi, 2008), kegiatan sekolah hijau 
meliputi 1) Program 5 R (Rethink, Reduce, Repair, Reause, Recycle; 2) Penghematan energi air dan listrik; 3) Penghijauan sekolah. Pendidikan lingkungan hidup bertujuan untuk membuat orang sadar lingkungan, sebagai bagian dari kesadaran yang bertumpu pada terbentuknya hubungan yang positif antara individu dan lingkungan alam, sosial dan lingkungan yang telah terbentuk dengan memperhatikan keteraturan hukum ekologi. Sasarannya adalah terbentuknya sikap yang sadar lingkungan yang berdasar pada nilai-nilai yang sesuai, semakin muda usia anak, pendidikan lingkungan akan semakin memberikan hasil yang positif. Beberapa persyaratan agar pendidikan lingkungan hidup berhasil (Turcotte, 2003): 1) Pendidikan lingkungan sebagai prinsip belajar menyeluruh (tidak terbatas jadwal); 2) Berorientasi pada proyek; 3) Lapangan ekologis tempat belajar. Integratif, konstruktif, partisipatif, dan kontekstual adalah alternative pendekatan lingkungan kepada anak. Strategi yang dapat ditempuh dapat melalui 2 alternatif (Sarwono, 1997; Suwarno, 2002 dalam Sumarmi, 2008), yaitu: 1) Pendekatan monolitikdan 2) Integratif. Pendidikan lingkungan dapat dimulai dari hal yang sederhana dengan melakukan kegiatan nyata sampai dengan kegiatan kompleks berupa penelitian. Konsep lingkungan hidup harus dimaknai tidak hanya sebagai wacana kurikulum saja tetapi diharapkan sudah mampu membentuk karakter siswa yang mampu mencintai lingkungannya. Agar siswa bisa memahami materi pelajaran dengan cepat dan mudah, guru diharapkan mengaitkan materi dengan konteksnya, tidak hanya menyangkut konteks lingkungan sekitar siswa tinggal, bersekolah, tetapi jauh lebih luas yakni bisa dikaitkan konteks pengalaman, minat, sosial budaya masyarakat, dan sebagainya. Pembelajaran kontekstual pada dasarnya bertujuan membantu guru mengaitkan antara isi materi pelajaran dengan situasi kehidupan nyata dari diri siswa dan berusaha memberi motivasi siswa untuk membuat hubungan antara pengetahuan yang sedang dipelajari dengan penerapan sehari-hari.

Ada 6 komponen yang harus diperhatikan dalam mengembangkan pembelajaran kontekstual: 1) Semua proses pembelajaran diberikan dan dialami siswa hendaknya bernilai positif serta mengandung relevansi yang tinggi; 2) hendaknya dapat diaplikasikan; 3) Siswa diajak untuk menggunakan kemampuan berpikir tingkat tinggi (kritis, analitis, kreatif); 4) Model pembelajaran kontekstual tidak perlu menggunakan /mengacu pada kurikulum khusus; 5) Kontektual, harus memperhatikan dan menghargai keberagaman nilai budaya/harus dapat mengakomodir; 6) Dibutuhkan jenis penilaian yang menggambarkan kemampuan nyata dari siswa (authentic assessment).

\section{Strategi Aplikasi Konsep Fitoteknologi pada Sekolah Hijau}

Model sekolah hijau senantiasa berkembang. Menerapkan konsep-konsep fitoteknologi dengan memanfaatkan fitoproses menggunakan tumbuhan untuk perancangan dan proses sanitasi lingkungan. Strategi yang dapat diupayakan adalah 1) menggunakan halaman sekolah sebagai sumber belajar, ditata, ditanami pohon pelindung dan produktif, kegiatan nyata pengelolalaan lingkungan sebagai upaya terciptanya fitostruktur yang menyediakan RTF penyerap karbondioksida dan pencegah dampak lingkungan; 2) praktek pengelolaan sampah, manajemen sumber daya air dan pengolahan limbah sebagai realisasi konsep fitoremediasi; 3) widyawisata ke lingkungan sekolah 
mencari tambahan pustaka mengenai pendidikan lingkungan hidup; 4) mencari ide untuk meningkatkan keterampilan guru membelajarkan PKLH; 5) mengadakan kesempatan untuk melaksanakan kegiatan lingkungan. Berkaitan dengan pengaplikasian konsep fitoteknologi, maka dapat dirancang sekolah hijau difasilitasi dengan kolam-kolam ikan dengan sumber air limbah domestik sekolah dari toilet, dapur, kantin sekolah dan sebagainya dalam lingkungan sekolah yang ditanami tumbuhan air yang memiliki kemampuan untuk menyerap bahan-bahan limbah.

Dalam aktivitas rumah tangga sekolah, berbagai macam limbah akan dihasilkan termasuk limbah logam berat yang sulit didegradasi. Walaupun memiliki limbah yang mengandung logam berat dengan jumlah relatif kecil, tetapi karena aktivitas rumahtangga sekolah terjadi terus menerus memungkinkan terjadinya penimbunan sehingga berpotensi menjadi besar, mencemari dan menimbulkan risiko lingkungan. Dalam aktivitas rumah tangga sekolah, logam berat dapat ditemukan pada bahan dan/atau bekas kemasan produk aktivitas dapur dan kantin (seperti kaleng aerosal, pembersih, penyemprot hama, pembersih saluran, pembersih lantai, pembersih jendela), toilet dan kamar kecil (seperti pembersih yang mengandung alkohol, pembersih kamar mandi dan toilet, pembersih permanen), garasi atau perbengkelan (seperti oli persneling, minyak rem, cairan pembersih mobil), dalam rumah (cairan pembunuh serangga dan gulma, dan lainnya (seperti bahan kimia sisa kegiatan praktikum), yang selanjutnya logam berat terbawa dalam limbah cair yang biasanya dibuang begitu saja di lingkungan sekitar atau sungai. Selain itu, logam dapat berasal dari tanah atau sumber air tanah (Fe misalnya), kontaminan oleh udara tercemar sekitar
$(\mathrm{Pb}$, dari jalan raya akibat kontaminasi asap motor/mobil), bahan-bahan aktif pembersih dan bahan makanan yang sudah tercemar logam berat $(\mathrm{Cd}, \mathrm{Pb}, \mathrm{Zn}$, As dan sebagainya), serta penggunaan pestisida. Menurut Connel \& Miller (2006), jumlah runutan yang cukup besar disumbangkan ke dalam cairan limbah rumah tangga oleh sampah-sampah metabolik, korosi pipapipa air $(\mathrm{Cu}, \mathrm{Pb}, \mathrm{Zn}$ dan $\mathrm{Cd})$ dan produkproduk konsumer (misalnya formula deterjen yang mengandung $\mathrm{Fe}, \mathrm{Mn}, \mathrm{Cr}, \mathrm{Ni}$, Co, Zn, B dan As). Kepekatannya seringkali beranah dalam miligram per liter tetapi beragam menurut faktor-faktor seperti pola penggunaan air, jangka waktu dalam tahun dan keadaan ekonomi konsumen. Komposisi logam yang terkandung dalam suatu ekosistem perairan, tergantung faktor perencanaan perkotaan, keadaan lalu lintas, konstruksi jalan, penggunaan tanah, ciri-ciri fisik dan klimatologi batas air.

Logam berat yang terbawa dalam air limbah termasuk di dalamnya rumah tangga sekolah, selanjutnya mengikuti aliran dalam kolam maupun tanah di sekitarnya. Tumbuhan budidaya maupun yang liar tumbuh di tempat tersebut atau memperoleh aliran limbah akan menerima logam berat dan akan mengakumulasinya dalam berbagai bagian organ.

Dengan demikian siswa dapat terjun langsung mengamati struktur dan proses pada berbagai tumbuhan yang ada, mengamati perubahan-perubahan dalam air buangan di kolam dengan mengukur dan mencatat beberapa parameter tertunjuk sesuai hasil penelitian, mengamati dan menggunakan objek-objek tumbuhan yang ada di sekitarnya, bahkan bisa juga mengamati pada ikan yang hidup di kolam, sebagai indikator terjadinya perbaikan mutu air oleh peranan tumbuhan air di kolam mapun yang ada disekitarnya. Konsep-konsep yang diperoleh merupakan 
konsep-konsep materi Biologi yang dapat membelajarkan siswa dan memberi peluang untuk membuka wawasan tentang solusi pemecahan masalah lingkungan secara berkelanjutan dengan memanfaatkan tumbuhan.

\section{KESIMPULAN}

Pada bagian penutup ini penulis menyimpulkan hal-hal sebagai berikut: 1) fitoteknologi berperan integral untuk perancangan dan proses sanitasi lingkungan; 2) sekolah hijau memiliki komitmen dan secara sistematis mengembangkan program-program untuk menginternalisasikan nilai-nilai lingkungan ke dalam aktivitas sekolah; 3) aplikasi konsep fitoteknologi merupakan strategi sistematis realisasi pembelajaran biologi pada program sekolah hijau.

\section{DAFTAR RUJUKAN}

Connell, Des. W. \& Miller, G.J. Kimia dan Ekotoksikologi Pencemaran. Terjemahan oleh Yanti Koestoer. 2006. Jakarta: Universitas Indonesia (UI-Press).

Handoyo. B. 2002. Model Sekolah Hijau Berbasis Sekolah Setempat di Sekolah Dasar Sekitar Sungai Bango Sawojajar Malang. Laporan Penelitian Tidak diterbitkan. Malang: Lemlit Universitas Negeri Malang.

Mangkoedihardjo, S. 2008. Integritas Fitoteknologi dalam Sanitasi Lingkungan untuk Pembangunan Berkelanjutan. Naskah Pidato Pengukuhan Guru Besar Ilmu Sanitasi Lingkungan dan Fitoteknologi. Fakultas Teknik Sipil dan Perencanaan, Jurusan Teknik Lingkungan. Institut Teknologi Sepuluh Nopember Surabaya. 26 Januari 2008.
Peer, Wendy Ann., Baxter, Ivan R., Richards, Elizabeth L., Freeman, John L., Murphy, Angus S. 2003. Phytoremediation and Hyperaccumulator Plants. Center for Phytoremediation, Purdue University, West Lafayette, IN 47907 USA.

Sumarmi, 2008. Sekolah Hijau Sebagai Alternatif Pendidikan Lingkungan Hidup dengan Menggunakan Pendekatan Kontekstual, Jurnal Ilmu Pendidikan, 15 (1); 19-25, 2008.

Susilo, H. 2001. Menggalakkan Pendidikan Lingkungan Hidup di Sekolah Dasar "Sekolah Hijau". Malang: Universitas Negeri Malang.

Turcotte, D. \& Villareal, J. 2003. Research on Developing Model for a Pilot "Green" School in the City Lowell. New York: Center for Family, Work, \& Community.

Walverton, B.J. and Mc Donald, R.J. 1979. Water Hyacinth and Alligator for Removal of Lead and Mercury From Polluted Water, NASA Tech, Memorandom, T.M - X - 72723. 
